\title{
The Relevance of Budug Basu Play with Fisherman's Life in Panjunan Village Cirebon
}

\author{
Rusman Nurdin \\ Postgraduate Doctoral Program of Arts Studies \\ Institut Seni Indonesia (ISI) Yogyakarta \\ Jalan Parangtritis KM. 6,5 Kotak Pos 1284 Yogyakarta 55188
}

\begin{abstract}
ABSTRAK
Pewarisan kekayaan lokalitas terus berlangsung sampai saat ini. Salah satunya adalah lakon Budug Basu. Pertunjukan lakon ini tampil dalam setiap kegiatan adat tradisi nelayan di Desa Panjunan Kecamatan Lemah wungkuk Kota Madya Cirebon, dalam pelaksanaan upacara Nadran. Peristiwa Nadran merupakan interupsi aktivitas keseharian nelayan dalam mencari sumber kehidupannya. Penelitian ini menggunakan konsep ritual Victor Turner tentang liminal-liminoid. Dalam konsep liminoid, masyarakat industri (urban) dengan kesibukannya tetap melaksanakan upacara dalam alur bekerja, bermain dan waktu luang. Kondisi ini menjadi titik temu dalam aspek kehidupan social nelayan saat ini. Penelitian ini menggunakan metode Etnografi dengan teknik pengumpulan data melalui studi kepustakaan, observasi dan wawancara sebagai proses untuk pengumpulan data-data di lapangan. Hasil penelitian ini menjelaskan bahwa upacara Nadran merupakan ungkapan ekspresi syukur yang dikontruksi sebagai peristiwa kebahagian, kegembiraan dan katarsis, sekaligus menciptakan ruang, waktu dan tempat dalam fenomena perwujudan sakralitas.
\end{abstract}

Kata kunci: kekayaan lokalitas, Lakon Budug Basu, simbol sakralitas

\begin{abstract}
The inheritance of local values continues to be spread to the new generation; one of them is Budug Basu play. The performance appears in every traditional activity of fisherman in Panjunan Village, Lemah Wungkuk District, Cirebon. The Budug Basu play is implemented in the Nadran ceremony. Nadran is an interruption of livelihood daily activities of fisherman in Cirebon. The ritual concept of Victor Turner's, namely "liminal-liminoid," suggests that industrial urban society still carries out the ceremony in their daily life activities. Currently, this condition becomes the meeting point in the social life of fishermen. This research uses ethnographic method with literature study, observation, and interview approaches as the process of collecting data. This study shows that Nadran ceremony is gratitude expression by being constructed through happiness, joy and cathartic while creating space, time and place in the phenomenon of the embodiment of sacred values.
\end{abstract}

Keywords: the richness of locality, Budug Basu play, sacred symbols 


\section{INTRODUCTION}

Fishermen rely their lives on the sea. Almost every day the fishermen go to the sea, if there are no obstacles facing them. When doing their jobs they face various conditions and risks. The sudden interruption in the middle of the sea makes the fishermen shocked, disappointed, depressed and helpless due to storms, leak boats, dead engines, missing or damaged nets, ship collision or disputes among crews. Events like that make the atmosphere tense, terrifying, frightening and worrying even sometimes takes casualties. When facing such disturbances, a crisis usually happens. But they always try to find a solution to overcome those various obstacles and threats. Either technical issue when dealing with all material aspects of facilities and infrastructure or non-technical issue potentially affects their behavior. Efforts are always made to

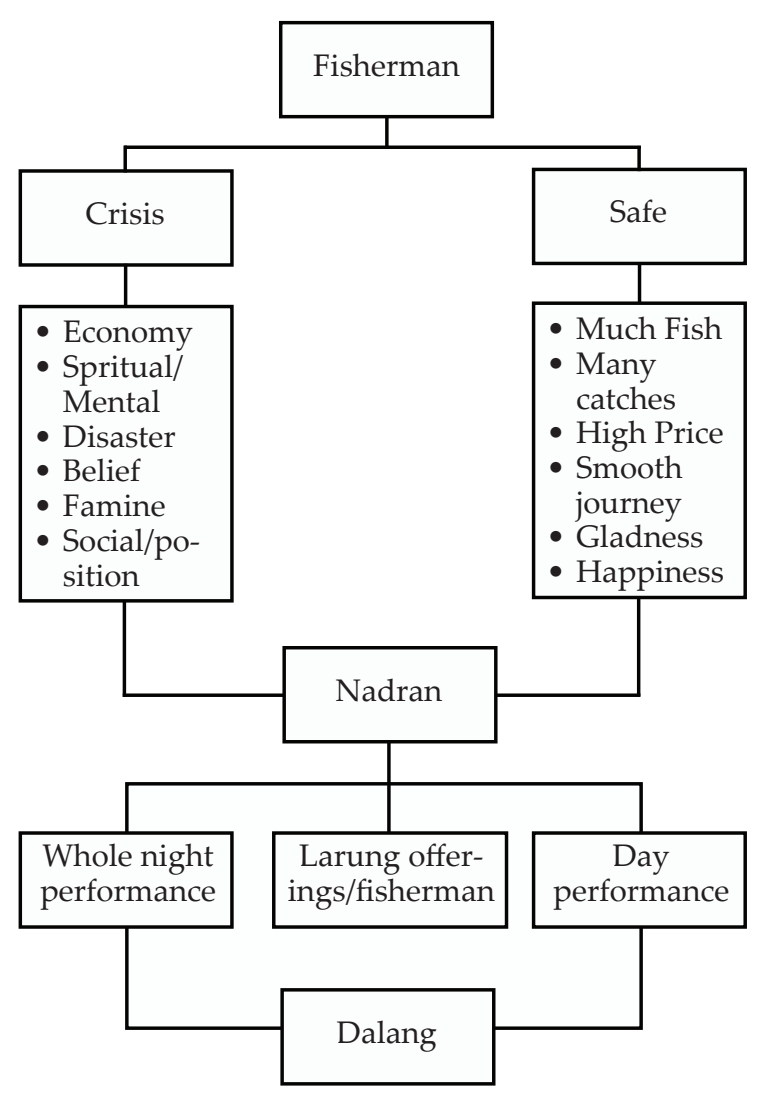

Figure 1. Identification of Nadran Ceremonial Activities minimize the crisis. Fishermen as a human being always try to escape the crisis by doing rituals (Dhavamony, 1995: 6-8).

On the other hand, fishermen always maintain the customs of their tradition, a moment that is always in their agenda up to recent time. They hold an annual celebration to keep the traditions called the Nadran ceremony alive. It is considered an interruption (pause) of life in daily activities. The pause is the implementation of the Nadran ceremony as an expression of mutual consciousness to express gratitude (Agustina, 2009: 44). On that basis, fishermen have responsibility for the grace of the sea as a source of life. Through the implementation of the Nadran ceremony, the integrity of fellow fishermen can be maintained, and also as their appreciation for life (Durkheim, 2005: 557-558). In addition to gratitude, the fishermen also beg for salvation, blessing and best results.

Figure 2 illustrates fishing as a form of immanent activity, while the ceremony of Nadran as a transcendental form. Two complementary activities that become nuances of life order of fisherman in Panjunan Village, Cirebon. These events are interesting to be studied further. As Peursen reveals

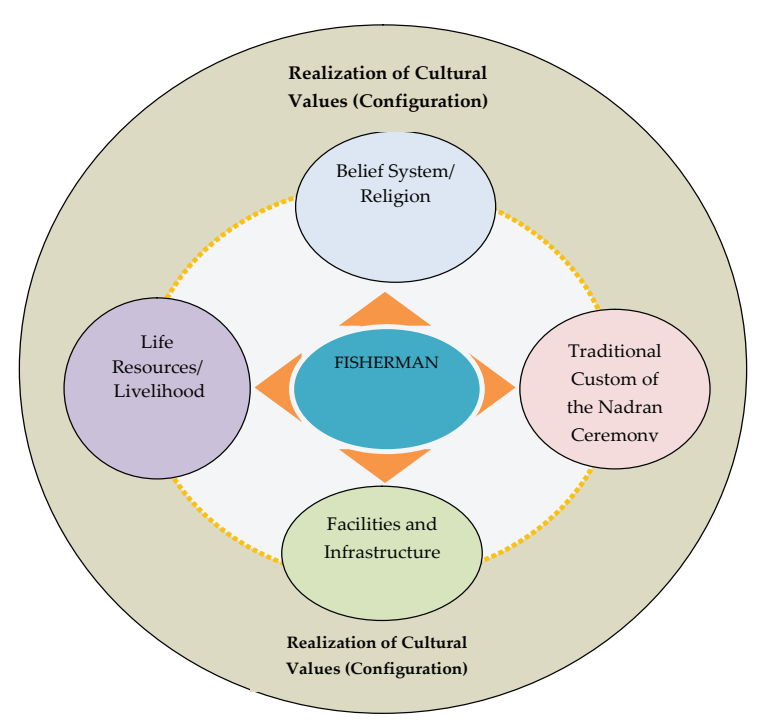

Figure 2. Cultural Activity of Cirebon Fishermen 
that both occupations create a harmonious condition as well as suggest that immanent life values are daily activities toward transcendental activity through the Nadran ceremony (Peursen, 1976: 15-17).

Both actions represent the aesthetic behavior and religiosity in the fisherman's life order, in which its implementation is in line with the social life dynamics of its society (Sumandiyo, 2006: xi-xii). Maintaining and caring for traditional customs is the basis of thought as well as ways of life, in any condition that is maintained and glorified. The ways to respect and care for the tradition are through the implementation of traditions understood together. Furthermore, the condition of this event will be studied further by borrowing Peursen's ideas about mythical, Ontological and Functional ideas.

\section{Nadran Ceremonial Events}

Nadran ceremonial events which are held every year is a manifestation of tradition. It is a social activity of the social heritage among generations practiced by its predecessors. The Nadran ceremony regularly conducted and maintained by over

The Nadran Ceremony Activities

Functionalism theory

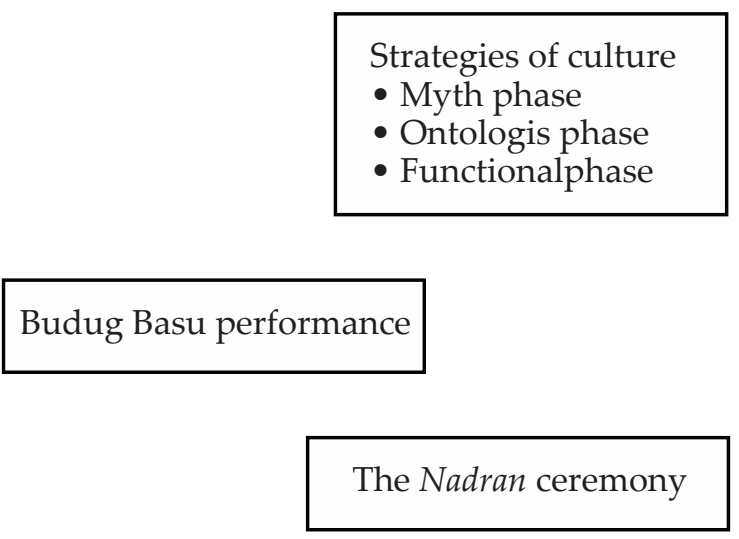

Figure 3. Synchronizing with Peursen View generations. This activity is based on their beliefs. In addition to fulfilling the desire of the faith aspect closely related to the order of religious values (Muhaimin, 2001: 39-52). This ceremony is important to be held. In his research Groenendeal mentions that ceremonial activity is a form of socio-religious activity, which puppet show is always presented (1987: 182-183).

In accordance with Nadran ceremonial events, the presence of shadow puppet (wayang kulit) is crucial. The shadow puppet performance gives both the aspect of life values and an outstanding contribution. In the Nadran ceremony, the shadow puppet is performed two times (Soetarno, 2004: 155-161); first, in the larungan event, which is performed a day before; second, in the Budug Basu performance, which is then followed by the ruwatan event for fisherman and his settlement as well as larungan offerings. Those two different activities mentioned above are connected and united in the aspect of value; that is immanent and transcendental behavior.

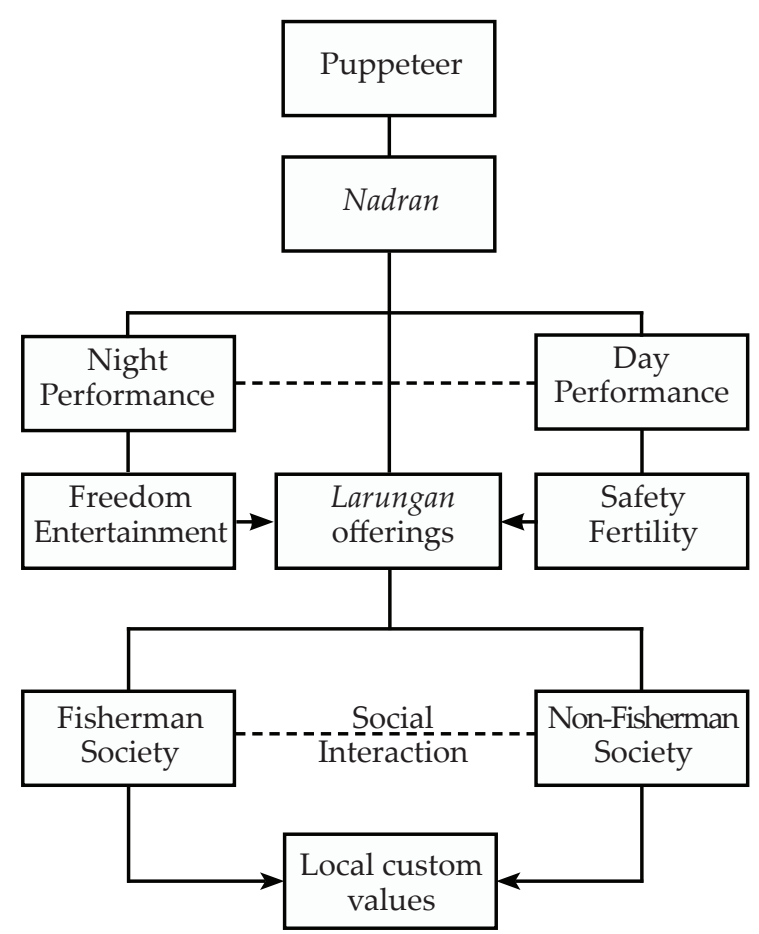

Figure 4. Nadran ceremonial process perspective 
A one-night shadow puppet performance is played on fishermen's demand. The story is usually emphasizing heroic stories. The show that reveals the order of life values, the values of truth, the struggle against the greedy rulers and those who molest people, are commonly performed. Such plays are a favorable performance for fishermen's introspection and contemplation. Those plays are also a reflection of the past life order that has been lived (Waluyo, 2000: 4-6). For those who live on the northern coast of Cirebon, it has its own life break as a way of doing introspection and reflection. They fulfill their desire by requesting songs to a sinden and practicing nyawer. For those who go to the sea, both requesting songs and practicing nyawer are the way to release daily lived tension. When the cere-mony is carried out, they do not do their routine work.

The conditions and situations experienced by the fishermen as shown in figure 4 , as revealed by Turner in the liminoid concept, begin with the liminality. Liminoid is a social condition of industrial society (urban). This concept is used to see and examine the current condition of fishermen. A social condition in the settlement of fisherman is currently very heterogenic; it grows and develops along with the continuous flow of urbanization. Not only fisherman, many urban residents also inhabit the area.

Such social conditions can be seen and analyzed through the concept of liminoid in ceremonial activities, as revealed by Turner, that is play and work, and spends time for rituals. They deliberately take the time to preserve their traditional customs through the ceremony and express themselves in the joy and happiness in realizing Nadran (Turner, 1982: 20-22). They have prepared themselves since several days earlier. Sailing equipment has been put away. As the main transportation, ships begin to enter the pier then remained inactive by the owner. This form of consciousness is the responsibility formed within every individual, taking the time to perform the ceremony. Awareness of not doing sea activities is a manifestation of honor with conditions like this they enter a sacred boundary (place, time, situation). It means routines are temporarily postponed and separated from their spirituals.

Fishermen in Panjunan Village only work and do their activities in preparation to perform the Nadran ceremony. They are eager to set up banners for the stalls before the Nadran ceremony comes. This preparatory work is commonly done by the fishermen community along the north coast of Cirebon. It signs that Nadran is shortly held in one of the coastal villages. Those signs signify the different life, and the fisherman begin the trading.

The fisherman perform their duties according to the results of the meeting. They have completed some of the preparation few days before the ceremony, including making a ship replica for placing the offerings. Fishermen's wives also do the same thing busy taking care of food, working happily. Some laugh cheerfully and tell each other about their own life experiences. Along with the concept of Turner's thought that what the fishermen do can be adjusted, thus the concept of liminoid can be used to see their working conditions.

\section{METHOD}

This research uses an ethnographic approach with the following steps: First, literature study; by exploring some writings that can be found as supporting materials. Second, interview; to obtain various data from informants as well as various community leaders who have competence associated with the process of this study. And third, 
observation; in this observation, researcher is directly involved in various events in the Nadran ceremony. The data obtained from the field supports the work of this study (Spradley, 1997: 3-13). Researcher attends to the series of events held or displayed in the Nadran ceremony.

It began from Arnold van Genap's mindset in "Rites de Passage", which is then focused on the second stage of the LiminalLiminoid situation and conditions by Victor Turner. The situation and conditions expressed by Tunner are about life and living the life. This concept was borrowed and used to see the condition and situation of fishermen in Panjunan Village in Cirebon. The principles of Turner's concept are applied to analyze the conditions and situations experienced by the fishermen, either individually or in groups which issimilar to the condition and social situation of the people in Ndembu (Turner, 1966: 19-20). The crisis encountered can become a conflict, consequently becoming anxiety in the journey of life and the lives of the fishermen.

\section{RESULTS AND DISCUSSION Performance of Budug Basu}

Shadow puppet with Budug Basu story, performed in the middle of the Nadran ceremony. This is held in the morning, at 08.00 until noon, and is continued with the ruwatan process. The essence of the story is that Budug Basu (Antasari) is Sanghyang Antaboga's (Antarasa) brother who met Dewi Tresnawati (Budug Basu and Dwi Tresnawati embodiment of two eggs) which was sent to Batara Narada, from Batara Guru. Both then got married. The marriage then turned into a disaster because they both eventually committed suicide. Knowing that Budug Basu had a disease and a fishy odor, Dwi Tresnawati ran away and crashed into the sacred $\mathrm{Cis}$ and died. Budug Basu then ran off to find his wife (Dwi
Trisnawati). Finding his wife dead, Budug Basu rammed himself into the same Cis. Shortly before the body of Budug Basu was buried, it turned into the fore runner of sea animal (Interview, Sudarso, June 25, 2014, in Cirebon).

\section{Performance Analysis of Budug Basu}

The story in Budug Basu artifacts provide clues that the sea is a male, represented by the fact that most fishermen are male. The tragic ending marriage of Budug Basu and Dewi Tresnawati's showed that incest should not take place. This means that Budug Basu and DwiTresnawati came from the same three types of eggs, namely the inability of Batara Guru to hold sadness and tears (Kalsum, Breeding of Paddy in Wawacan Sulanjana, wacana nusantara.org, accessed on 24 Dec 2014).

Both Budug Basu story and larungan become special event for the fishermen and the people who attend the events. Both rituals reveal the symbols of the aspects of sacred values that are an important momentum for fishermen. Through the procession of ceremonies of Nadran, the materials transformed into something meaningful for fishermen. According to Eliade, the process is closely related to the past that is the beginning of the creation of a source area of life along with divine powers (1987: 53-55). The meaning for fishermen cannot be separated from the symbol of fertility, in their activities to fish in the sea. Presenting the symbols creates fishermen's inner resilience.

The results of interviews with fishermen from various residential areas along the coastal coast of Cirebon reveal how to deal with life at sea while fishing. The results provide information that mood and condition of the so-called "crisis" are presence when disaster occurred at sea. It is proved that the activity of fishermen in the livelihood was not at all forgetting or leaving the custom of tradition. One of the tra- 


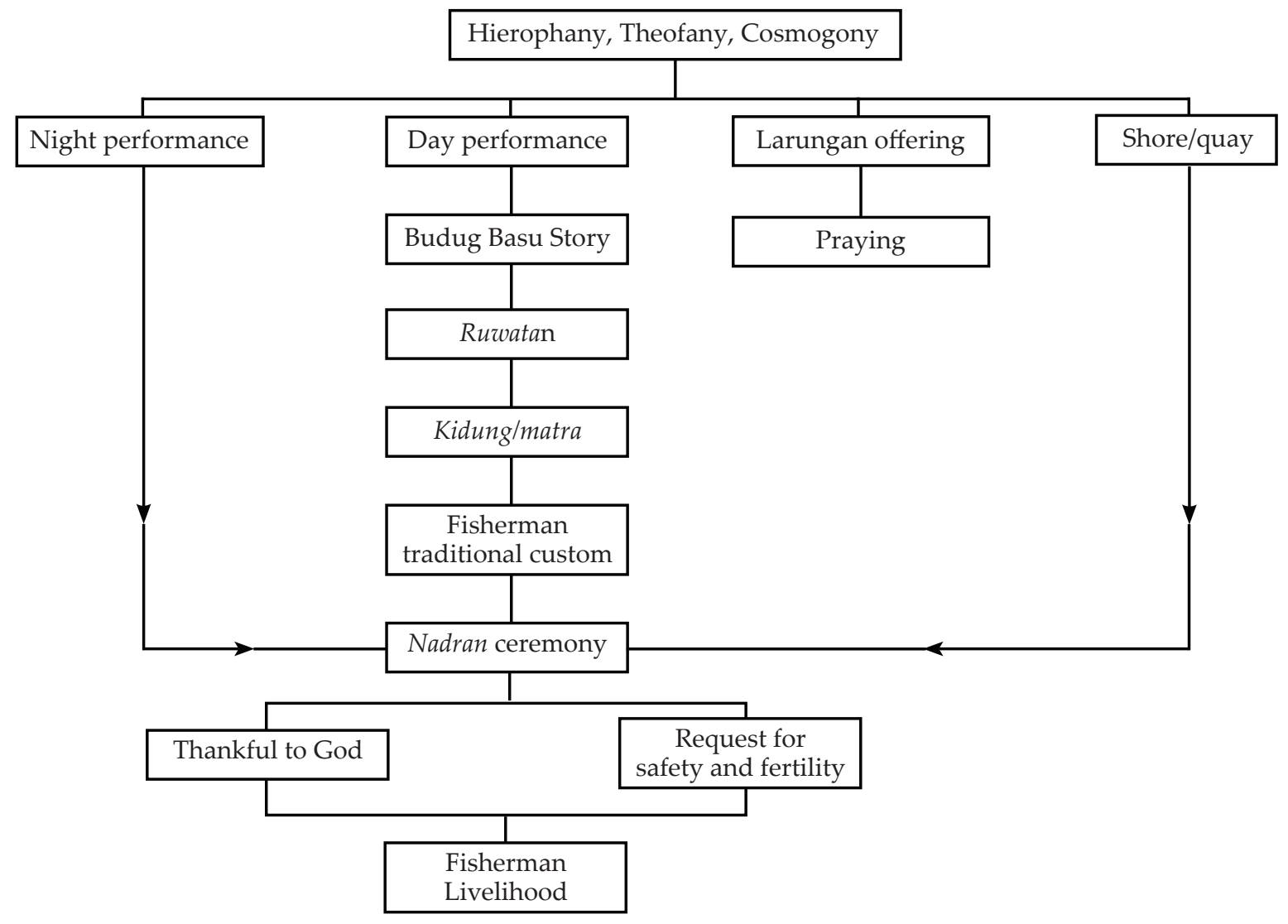

Figure 5. Mircea Eliade of Sacral Embodiment

ditions is to carry out Nadran, which is held annually. Fishing activities as the people's main earnings and performing Nadran are an inseparable ${ }^{1}$.

The researcher borrows van Peursen's concept of myth, ontology, and functions, to reveal the phenomenon happened among fishermen in the Panjunan Village, Cirebon. These three concepts of thinking show the direction of traditional aspects performed by the fishermen in Panjunan Village. Another concept of van Peursen shows the changing stage from immanent to transcendent, from daily activities to performing rituals. This concept can be seen from the ceremony conducted by the fishermen, which will create atmosphere and conditions that are different from daily life.

To illustrate that a risky situation is a transcendental disaster as the water explosion in the sea, which affects the aspects of the community's social life, especially the fisherman's family who go to the sea. The crisis endangers their presence or lives because of the disasters at sea, and the social crisis faced on land. For fishermen, social crisis events in life not only take place on land but also at sea where the incident of social crisis and various

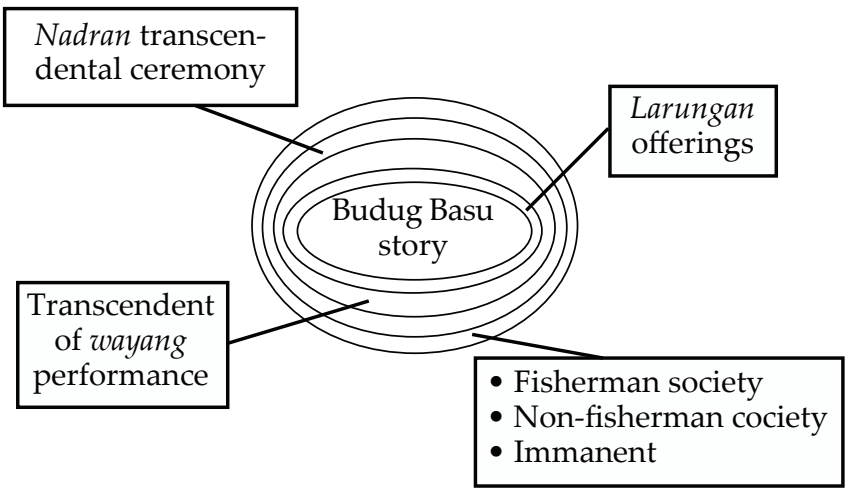

Figure 6. Budug Basu play as ruwatan media 
events can appear while looking for fish. Not to mention a crisis with the surrounding natural ecology system at sea. The crisis phenomenon faced by the fishermen can be something that is alarming, terrible, gripping, shaking and destabilizing their existence as fishermen.

However, the sea is a source of fishermen's income, namely as an unlimited area for catching fish and other species of animals. Speaking of the life crisis described above, it is difficult to predict when it has occurred. It may appear due to ship leakage, engine malfunction or weather changes, especially the wind that causes big waves. Wind changes the fish concentration that makes the fishermen go home without any catch. It becomes more complicated when fishermen face the problem of social crisis with their fellow fishermen, such as in terms of competition at sea. When it occurs and cannot be resolved, it can possibly take their lives and other fishermen will easily be aware of that incident that just happened. Such crisis is inevitable, but fishermen can still perform their jobs at sea.

Working at sea is heavier than on land, but fishermen still go to sea every day. Friendship with the sea is something that is interesting and unique to the fishermen despite the unpleasant happening that is inevitable. However, there are joy, happiness, and excitement when they are able to get a very satisfying catch. Therefore, fishermen, either as a group or individual, have a way to express their gratitude and to appeal to the Almighty, which principles and procedures are practiced based ontheir traditional custom by holding the annual ceremony.

The activities of the Nadran ceremony, which is a guideline of traditional customs to express of gratitude Fishermen, are started from the problems of the crisis faced by fishermen. The steps they take to realize their traditional customs activities cannot be separated from their past. Traditional heritage continued to grow along with the social development of its people. The transfer of generations in the social environment of fishermen society is not influenced by the social development of its era. Therefore, the process of inheritance is still running along with the growth of its next generation, which is still together in the same environment. The activity of gratitude has an important meaning in fishermen's lives; by carrying out the activity of syukur means the fisherman has the awareness to the attitude of trust and religion highly. Therefore, the Nadran ceremony has another purpose that is a manifestation of the expression of the system aspects of their belief values. For the fishermen, the Nadran ceremony has become their lifestyle. The Nadran ceremony must be carried out once a year, depending on the various aspects that support it, especially funding. The place of execution around the source of their life is, at the wharf, a harbor and the fish auction place.

The researcher argues that the Nadran ceremony performed by the fishermen community in the Village Panjunan, Cirebon, is an annual ceremony (ritual) as a form of their expression. The ceremony is an effort to cleanse and encourage life once a year through the days, months. The job is in the

Bebarit Management at Serentaun Ceremony Cigugur Kuningan

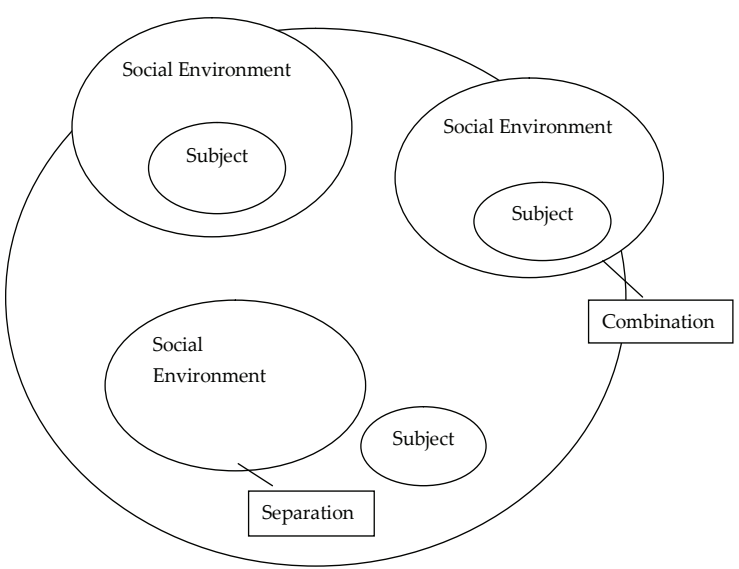

Figure 7. Pattern “Rites De Passage” of van Genap 
sea, which cannot be separated from the crisis problem (above already disclosed). An action needs to be done for their inner fulfillment; so that in the course of their life the fishermen obtain serenity, happiness, harmony, peace, prosperity, and blessing (Eliade, 1991: 18-21).

Researcher borrowed the concept of ritual thinking of Arnold van Genap, namely "The Rites of Passage," to categorize the crossing ceremony experienced by the fishermen. The steps Van Genap discloses as follows: first, separation; second, marginalization; and third, reunion. Van Genap's concept of thinking was then followed by Victor Turner, but the focus was on the second steps, which is marginalization, or threshold or liminal (Turner, 1974: 231234).

The concept of Arnold van Genap and Victor Turner are basically the concept of action or behavior of subjects who are worried and anxious living their lives. A condition and situation experienced by subjects, namely social status changes and lifecycle status. The ceremony also applies to subjects who will pass through periods of changes, from children to adulthood and adulthood to marriage and death. Victor Turner observed the social community of Ndembu with the dimension of crisis aspect they experienced. The social crisis of the Ndem-

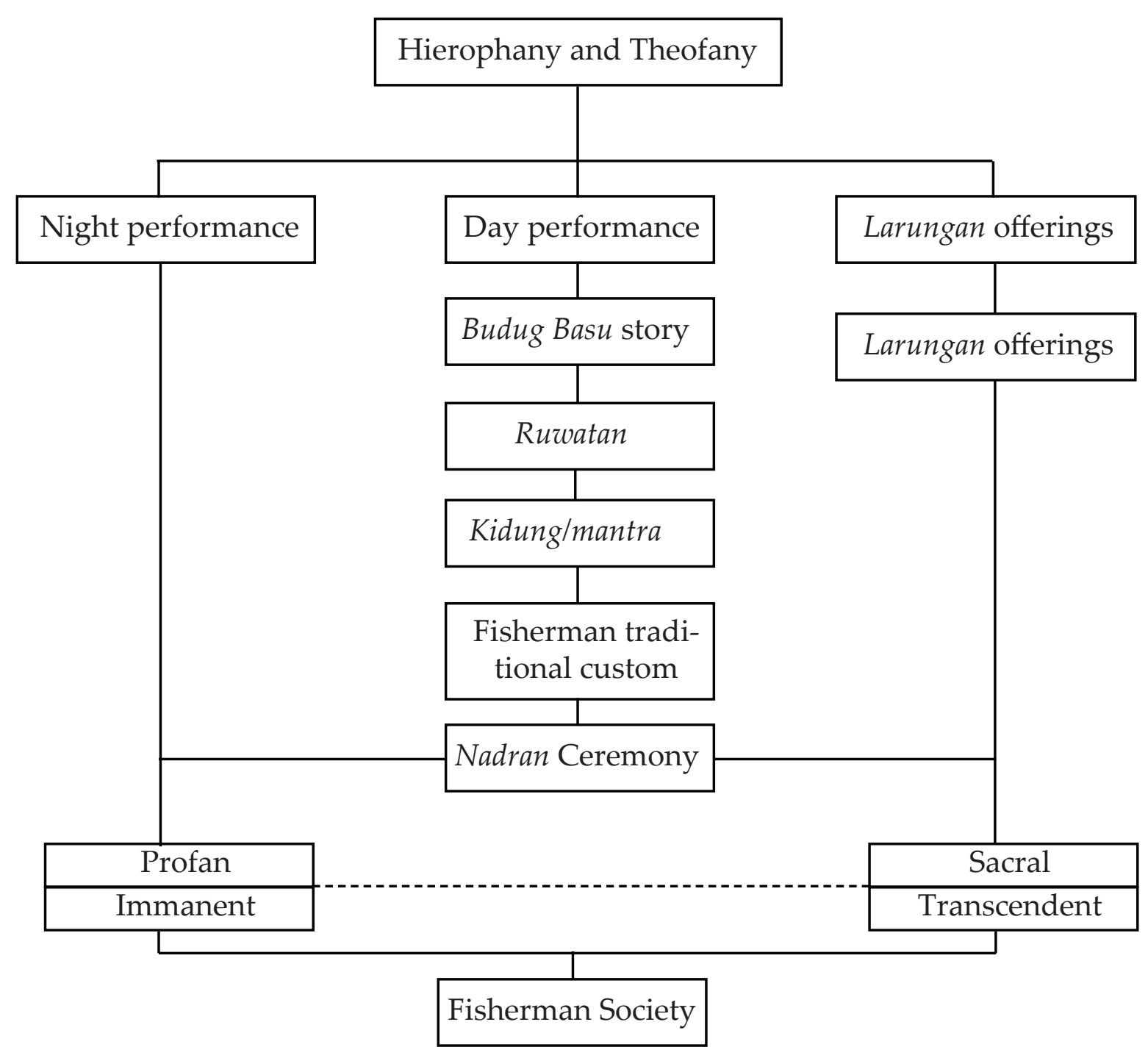

Figure 8. Relationship between the Nadran ceremony and society 
bu's community is initially centered on the concept of matrilineal, then the marriage events between their families (Turner, 1966: 19-20). The event of marriage is important because it becomes early changes in their attitudes. The changing process is not easy or smooth but through conflict from both parties. Similar to the paternal lineage, the maternal lineage with its descendant and their attitude do not accept the changes. In facing such conditions and situations, problems arise, in this case, "conflict" between them (Turner, 1994: 5-11).

\section{CONCLUSION}

The work of fishermen at sea will be different compared to the work of people whose source of life is on land. The difference is how to deal with disturbances and various obstacles. The event remains addressed with all strength and patience. For fishermen, the sea is the only place where they can work for the living. Conditions and events that appear in the sea can be a threat toa mental crisis of fishermen's behavior. Fishermen still need to do various efforts to overcome those potential problems. Efforts are made through ceremonies, and at the same time expressing gratitude and pleading of salvation. Nadran ceremonial event is a manifestation of symbols of the aspects of fisherman's tradition, containing the order of fishermen's values of life. A philosophical foundation rooted in religious beliefs and local cultural values held by local fishing communities (Heriyani, 2009: 7). The manifestation of the fishermen's actions and behavior cannot be separated from the aspect of hereditary beliefs, although in fact it is never revealed. It is about how the next generation who has undergone social changes among fishermen. Changes in various aspects of life, including the technology of machines for ships and other aspects that fishermen use seem to have no effect. Although fishermen have turned to technolo- gical developments, it is interesting that the symbols of his tradition are still carried out sincerely through his behavior and actions.

\section{End Note}

${ }^{1}$ Interview, Robby, 48 years old, head of the fishermen group, GrogolBondet, Gunung Jati Sub-district Depok, Cirebon block, 15 November 2015 .

\section{Bibliography}

Dhavamony, Mariasusai

1995 Fenomenologi Agama. terj. Diryakara. Yogyakarta: Kanisius.

Durkheim, Emile

2005 The Elementary Forms of the Religious Life, Sejarah Agama. (terj. Muzir Ridwan Inyiak, cetakan ke II. Yogyakarta: IRCiSoD.

Eliade, Mircea

2002 Sakral dan Profan, terj. Nuwanto. Yogyakarta: Fajar Pustaka Baru.

1991 Mitos Gerak Kembali yang Abadi, Kosmos dan Sejarah, terj. Ananta Cuk. Yogyakarta: Ikon Teralitera.

1987 Mitos, menurut Pemikiran Mircea Eliade, terj. Susanto Hary P.S. Yogyakarta: Kanisius.

Groenendael, Clara van Victoria M.

1987 Dalang di Balik Wayang. Jakarta: PT. Temprint.

Heriyani Agustina

2009 Nilai-Nilai Filosofi Tradisi Nadran Masyarakat Nelayan Cirebon. Yogyakarta: Kepel Press.

James, Spradley P.

1997 Metode Etnografi, terj. Amri Marzali. Yogyakarta: PT. Tiara Wacana. 
Kanti Walujo

2000 Dunia Wayang Nilai Estetis Sakralitas dan Ajaran Hidup. Yogyakarta: Pustaka Pelajar.

Lewandowski, A. Glen

1994 Ritus Adat Inisiasi, Tahap Liminal pada Rites de Passages. Victor Turner, Seri Pastoral 234 no 5. Yogyakarta: Pusat Pastoral.

Muhaimin AG

2001 Islam dalam Bingkai Budaya Lokal Potret dari Cirebon. Jakarta: Logos Wacana Ilmu.

Peursen, van c.a

1976 Strategi Kebudayaan, terj. Hartoko Dick. Jakarta: Kanisius dan BPK Gunung Mulia.

Soetarno

2004 Wayang Kulit Perubahan Makna Ritual dan Hiburan. Surakarta: STSI Press.

Turner, Victor

1994 Ritus Adat Inisiasi, Tahap Liminal pada "Rites de Passages". Seri Pastoral 234. Yogyakarta: Pusat Pastoral.
$--$

1982 From Ritual to Theatre: The Human Seriousness of Play. Performance Studies Series. Performing Arts Journal Publications.

1974 Dramas, Fields and Metaphors, Symbolic Action in Human society. Ithaca and London: Cornell University Press.

1966 The Forest Of Symbols, Aspect of Ndembu Ritual. Cornell Paperbacks. Ithaca and London: Cornell University Press.

Y. Sumandiyo Hadi

2006 Seni dalam Ritual Agama. Yoyakarta: Pustaka.

Webtography:

Wacananusantara.org, Pemuliaan terhadap Padi dalam Wawacan Sulanjana, Kalsum Penulisan Cerita Budug Basu di Kalangan Keraton Cirebon, 5 July 2013 LK, accessed on 24 Dec 2014. 